Biljana Mirković

University for Business Engineering

and Management, Banja Luka

(Bosnia and Herzegovina)

\section{Svetlana Čizmić}

University of Belgrade

Department of Psychology
УДК: 331.56(497.6)

Ориіиналан научни рад

Примљен: 28. 11. 2011.

\title{
ACTIVE JOB SEARCH: THE INFLUENCE OF SOCIO-DEMOGRAPHIC CHARACTERISTICS
}

Unemployment is a stressful experience since it puts a person in an insecure situation and requires various changes in a person's everyday life. Active job search is an important predictor of finding a job. Findings on the factors of differences in willingness for an active job search are significant and useful in creating counselling models for the unemployed. The aim of this study was to examine the influence of socio-demographic characteristics on the choice of strategies used to cope with unemployment stress and on willingness to try out various forms of active job search, as well as to determine whether willingness for active job search can be predicted based on particular strategies for coping with stress caused by unemployment. The sample of participants included 304 unemployed persons registered with the Employment Service of the Republic of Srpska in Banja Luka. The scales used in the study included the aspirations scale and employment expectations scale, the scale of strategies for coping with unemployment stress, the scale of willingness to try out forms of active job search; and the socio-demographic characteristics questionnaire. The results showed that the socio-demographic characteristics such as gender, age, level of education, length of the unemployment period and material circumstances affected the choice of a stress coping strategy. Willingness to try out forms of active job search is affected by socio-demographic characteristics such as gender, age, level of education and material circumstances. It was also found that the problem-focused strategies for coping with unemployment stress were significant predictors of willingness for active job search.

Key words: unemployment, stress, active job search, Republika Srpska

\section{Introduction}

Work is an integral part of each person's life from entering adulthood to the old age. Getting a job is important for an individual not only because of the economic security but also for meeting other needs such as self-esteem and self-actu- 
alization. The fact of doing a job people are paid for gives them a feeling that their work is socially valuable, which is how they earn the respect of other people and develop self-esteem as well. If they additionally develop their own skills and feel satisfied, their highest needs - those for self-actualization - are being at least partially fulfilled. Also, by providing the economic security, and being the source of identity and self-esteem, sometimes even of self-actualization, work also offers social interaction and structures the individual's time (Šverko, 1991).

Given the importance of employment, we are not surprised by many findings (Cassidy, 1994, 2001; Broman, Hamilton \& Hoffman, 2001; Goldsmith \& Veum, 1996) that the loss of a job and unemployment are stressful experiences. The loss of a job is placed in the top quarter of the Stressful Life Events Scale by Holmes $\&$ Rahe (1967) and is considered one of the ten most traumatic events in life (Hanish, 1999).

According to Lazarus (Lazarus \& Folkman, 2004), stress is the result of an individual's appraisal that his/her relationship with the environment has been disturbed. The central place in the Lazarus's model of stress, the most accepted one today, is occupied by the appraisal of importance of events and appraisal of the possibility of influencing the event, that is, the appraisal of the likelihood of a positive outcome of the event. The unemployment stress is the result of an individual's appraisal of importance of employment and appraisal of the likelihood of fulfilling this goal - getting a job (Vukelić, 2003). Namely, when an individual appraises getting a job as very important, but a positive outcome - employment is not appraised as likely to happen, then frustration is developed, which, according to Lazarus (1966), directly affects the experience of stress.

When people find themselves in a stressful situation, they try to deal with it in a certain way, i.e. they try to face what happened to them. One way of coping with a stressful situation is to change the situation causing the stress - problemfocused coping, while the other way is to regulate emotional reactions caused by the stressful situation - emotion-focused coping (Lazarus \& Folkman, 2004). Emotion-focused coping involves individual mechanisms, so-called strategies such as: wishful thinking, self-blame, retreat to loneliness, repression and avoidance, tension decrease, turning to religion, reconciliation with destiny, seeking emotional support from other people, etc. (Lazarus \& Folkman, 2004) Problemfocused coping includes: targeted problem solving, planning, opposing, negotiating, searching for the information and material support from other people, etc. (Lazarus \& Folkman, 2004) None of the coping ways in itself is either "good" or "bad". However, problem-focused coping is more useful than emotion-focused 
coping when estimating the "benefit" in the long run, i.e. in shaping the long-term consequences (Lazarus \& Folkman, 1984).

The chosen way of coping with a stressful situation depends on the characteristics of an individual and the characteristics of a situation (Lazarus \& Folkman, 2004). The individual influence of each of these factors varies from situation to situation. Based on the results of his researches, Arambašić (2003) claims that whether someone is going to avoid to even think about being the unemployed or actively solve his/her problem is more determined by the characteristics of an individual than the objective facts and information he/she has.

From their research, Stone and Neale (1984) found that men use more problem-focused coping strategies as opposed to women who use more emotionfocused coping strategies. Leana and Feldman (1991) also found that men rely more on problem-focused coping (e.g. searching for a job), while women rely more on emotion-focused coping (e.g. seeking social support from friends and family). However, some researches produced only partial gender-wise differences in the use of the coping model. For example, Smari et al. (1997) discovered that unemployed men used more problem-focused coping, while no gender-wise differences were recorded in the use of emotion-focused coping.

As far as the age is concerned, Leana and Feldman (1992) found that younger unemployed persons used more problem-focused strategies for coping with the unemployment than older people who used more emotion-focused coping strategies. Age was also found to be a significant predictor of the unemployment period. Older people stay unemployed for longer periods of time (Leana \& Feldman, 1992).

When it comes to the level of education, people with higher education were found to use problem-focused strategies for coping with the unemployment stress more often. These people are also more optimistic in terms of employment opportunities (Gowan \& Gatewood, 1997).

A number of previous studies of coping with the unemployment stress (Leana $\&$ Feldman, 1992) have also indicated that at the beginning of the unemployment period, the unemployed more often use the problem-focused coping strategies. However, the longer the unemployment period, the more people use emotionfocused coping strategies.

Several studies (Vinokur \& Caplan, 1987; Wanberg, Watt \& Ramsey, 1996) point to the connection between reduced financial circumstances and more frequent use of problem-focused strategies for coping with the unemployment stress.

Active job search is the most important predictor of finding employment (Kanfer et al., 2001). According to the standard definition of unemployment, 
active job search includes: registration with public and private employment services and contacting them for the purpose of obtaining the information about the employment possibilities, enquiring with and seeking help from friends or relatives, placing and answering employment ads, and applying for permits, licenses or financial sources for starting one's own business (Hussmanns et al., 1990).

Studies show that the way people behave while job seeking is related to their individual characteristics.

Thus, in their meta-analysis Kafner et al. (2001) proved that older people, women, less educated and those unemployed for a long time are less engaged in finding a job than younger people, men, more educated and those unemployed for a short period of time.

Petrović, Čizmić and Kovačević (2009) have also confirmed that the unemployed holding college or university degrees search for a job more intensively than the unemployed with elementary and high school degrees.

In a study on gender and methods of job search, Huffman and Torres (2001) discovered the differences between men and women in using formal and informal sources of information about the labour market opportunities. Men were more often found to use the informal sources of information about the labour market opportunities (friends and relatives) and to apply for a job directly. On the other hand, women more frequently used newspaper ads as a source of information about the labour market opportunities and referred to recruiting agencies for help. Daniel (1990) also discovered that women relied more on formal methods of job seeking. He also stated that women were more likely to find a job through the employment services as they have a more favourable opinion on these institutions than the unemployed men. Contrary to them, men are more inclined to a more speculative approach to employers and more intense use of their personal and business network while seeking employment.

When it comes to financial needs, Wanberg et al. (1999), Kanfer et al. (2001), and Andrić (2001) and Pejaković (2009) determined that the unemployed with greater financial difficulties look for a job more intensively. The unemployed enjoying higher unemployment benefits are less active in job search and stay unemployed for a longer time.

Finally, it should be noted that, although active job search leads to a desired goal - getting a job - it does not necessarily lead to a guaranteed success. Namely, the possibility of getting a job also depends on some other factors over which the unemployed person has no control at all, such as a situation at the labour market. For that reason, active job search can often be very discouraging. 
It is often hard or impossible to include the behaviour itself in the study. Considering a large number of empirical findings indicating that one's willingness to adopt a particular behaviour is highly linked to one's actual behaviour and that it is one of its basic determinants, it is often used in studies as a substitute measure of behaviour (Pennington, 1997).

Findings on the factors of difference in willingness to undertake activities aimed at obtaining employment are important and useful in creating counselling methods for the unemployed.

The goals of this study included the following:

1. To determine if and in which way socio-demographic characteristics of the unemployed influence the choice of strategies for coping with unemployment stress;

2. To determine if and in which way socio-demographic characteristics of the unemployed affect the willingness to try out different forms of active job search; and

3. To prove that willingness to try out different forms of active job search can be predicted from the strategies for coping with unemployment stress.

\section{Method}

\subsection{Research Method and Sample of Participants}

The study included 318 unemployed people registered with the Employment Service of the Republic of Srpska, located in Banja Luka. Considering one specific aspect of this study, coping with unemployment stress, it was necessary to make sure that all participants in the sample experienced unemployment as a stress. Consequently, for each participant we established the intensity of pressure caused by unemployment. The intensity of pressure was defined as a difference between the intensity of aspirations and intensity of expectations about employment $(\mathrm{P}=$ A - E). Theoretical range of the pressure calculated in this way was between -4 and 4. A positive result was an indication of pressure, while negative values and zero suggested the absence of pressure. All participants whose intensity of pressure due to unemployment was less than or equal to zero were subsequently excluded from the initial sample, leaving 304 participants in the final sample (unemployment is a stressful experience for as much as $94 \%$ of the participants included in the study). Table 1 shows the structure of the sample by gender, age, level of education, length of unemployment and material circumstances. 
Table 1: Structure of the Sample by Gender, Age, Level of Education, Length of Unemployment and Material Circumstances

\begin{tabular}{|c|c|c|c|}
\hline & & Frequency & Percentage \\
\hline \multirow[t]{2}{*}{ Gender } & Male & 145 & 47.69 \\
\hline & Female & 159 & 52.31 \\
\hline Total & & 304 & 100.00 \\
\hline \multirow[t]{5}{*}{ Age } & 25 and younger & 19 & 6.25 \\
\hline & $26-35$ & 150 & 49.34 \\
\hline & $36-45$ & 63 & 20.72 \\
\hline & $46-55$ & 64 & 21.05 \\
\hline & $56-65$ & 8 & 2.62 \\
\hline \multicolumn{2}{|l|}{ Total } & 304 & 100.00 \\
\hline \multirow[t]{5}{*}{ Level of education } & Elementary school degree or less & 26 & 8.55 \\
\hline & $\begin{array}{l}\text { Two- or three-year school degree for } \\
\text { skilled or highly skilled workers }\end{array}$ & 53 & 17.43 \\
\hline & High school degree & 138 & 45.39 \\
\hline & College degree & 33 & 10.85 \\
\hline & University degree or higher & 54 & 17.76 \\
\hline Total & & 304 & 100.00 \\
\hline \multirow[t]{2}{*}{ Length of unemployment } & Short (up to 6 months) & 18 & 5.92 \\
\hline & Medium ( 7 to 36 months) & 97 & 31.91 \\
\hline \multirow[t]{2}{*}{ period } & Long (more than 36 months) & 189 & 62.17 \\
\hline & & 304 & 100.00 \\
\hline \multirow[t]{4}{*}{ Material circumstances } & Far below the average & 101 & 33.22 \\
\hline & Just below the average & 65 & 21.38 \\
\hline & Average & 126 & 41.45 \\
\hline & Above the average & 12 & 3.95 \\
\hline Total & & 304 & 100.00 \\
\hline
\end{tabular}

The study was conducted in July 2008. The survey was carried out ten times in a month in order to avoid the impact of the beginning, middle or the end of the month to the choice of participants. They filled in the questionnaires on their own in the offices of the Employment Service, and were told the information would be used only for research purposes.

\subsection{Instruments}

The Aspirations Scale (Vukelić, 2003) was used to examine the intensity of aspirations or the level of importance that the unemployed attach to the aim of their own employment. The scale contained seven statements. Participants used a five-degree Likert-type scale to determine to what extent the given statement was true for each of them. Cronbach's Alpha was .65. 
The intensity of expectations or perceptions of likelihood of achieving the goal (employment) was examined with the Expectations Scale (Vukelić, 2003). The scale contained five statements. Participants used five-degree Likert-type scale to determine to what extent the given statement was true for each of them. Cronbach's Alpha was. 70.

Strategies for coping with unemployment stress were examined with the Scale of Strategies for Coping with Unemployment Stress (Davidović, 2003). The scale contained twenty statements grouped into five subscales used to examine three emotion-focused coping strategies: expressing emotions, passivation and reconciliation with destiny; and two problem-focused coping strategies: planning and taking action, and reinterpretation. Most of the statements presented in the scale were taken from the original Lazarus stress coping scale (Lazarus, 1966) and modified for the unemployment situation. Participants used a four-degree Likert-type scale to assess how often in the last three months they behaved and/or thought in the manner given in the statement. Cronbach's Alpha was .78 for the Expressing Emotions Scale, .67 for the Passivation Scale, .73 for the Reconciliation with Destiny Scale, .67 for the Planning and Taking Action Scale, and .69 for the Reinterpretation Scale.

Willingness for an active job search was examined with the Willingness for an Active Job Search Scale (Davidović, 2003). The scale contained eleven statements grouped into four subscales used to examine four forms of active job search: corruptive behaviour, accepting a job in another city, accepting a job not related to one's own profession or qualifications, and usual activities. Participants used a five-degree Likert-type scale to assess the extent to which they agreed with the statement. Cronbach's Alpha was .86 for the Corruptive Behaviour Scale, .84 for the Accepting a Job in Another City Scale, .67 for the Accepting a Job not Related to One's Own Profession or Qualifications Scale, and .81 for the Usual Activities Scale.

The Socio-Demographic Characteristics Questionnaire was used to examine the socio-demographic characteristics. The questionnaire consisted of five questions about the following socio-demographic characteristics: gender, age, length of unemployment, level of education and material circumstances.

\subsection{Statistical Analysis}

Statistical procedures used to analyze the data included the following: multivariate analysis of variance, LSD test, Mann-Whitney test and multiple regression analysis. Data analysis was performed using the statistical software package SPSS for Windows, version 16.0. 


\section{Results and Discussion}

\subsection{Effects of Socio-Demographic Characteristics on the Choice of Strategies for Coping with Unemployment Stress}

Multivariate analysis of variance and post hoc test - LSD test were used to determine the effects of socio-demographic characteristics on the choice of strategies for coping with unemployment stress. Mann-Whitney Test was used to determine the differences between the dichotomic (gender-related) groups.

When observing the common variance of strategies for coping with unemployment stress, four examined socio-demographic characteristics - gender, age, education and material circumstances (Table 2) were found to have a significant effect. The length of the unemployment period does not affect the common variance of the stress coping strategies.

Table 2: Socio-Demographic Characteristics and Common Variance of Stress Coping Strategies

\begin{tabular}{lcccc}
\hline \hline Socio-demographic characteristics & $\mathrm{F}$ & $\mathrm{df}$ & Error df & Sig. \\
\hline Gender & 8.532 & 5 & 298 & .000 \\
Age & 1.741 & 20 & 1192 & .022 \\
Level of education & 2.964 & 20 & 1192 & .000 \\
Material circumstances & 3.612 & 15 & 894 & .000 \\
\hline \hline
\end{tabular}

Individually observed, all examined socio-demographic characteristics affect the stress coping strategies.

Gender significantly affects two emotion-focused stress coping strategies expressing emotions $(U=7502.500$; Sig. $=.000)$ and passivation $(U=7782.500$; Sig. $=.000)$ and one problem-focused stress coping strategy - planning and taking action $(\mathrm{U}=9601.000 ;$ Sig. $=.011)($ Table 3$)$.

Table 3: Mean Ranks and Mann-Whitney Test for Gender, Expressing Emotions, Passivation and Planning and Taking Action

\begin{tabular}{llcccc}
\hline \hline Stress coping strategies & Gender & $\mathrm{N}$ & Mean Rank & $\begin{array}{c}\text { Mann-Whitney } \\
\text { U: }\end{array}$ & \multirow{2}{*}{ Sig. } \\
\hline Expressing Emotions & Male & 145 & 124.74 & 7502.500 & .000 \\
& Female & 159 & 177.81 & & .000 \\
\hline Passivation & Male & 145 & 126.67 & 7782.500 & .011 \\
& Female & 159 & 176.05 & & \\
\hline Planning and Taking Action & Male & 145 & 164.62 & \multirow{2}{*}{9601.000} & \\
& Female & 159 & 139.21 & & \\
\hline \hline
\end{tabular}


Females were found to be more inclined to cope with unemployment stress with emotion-focused strategies - expressing emotions and passivation, while males used more problem-focused strategies - planning and taking action (Graph 1).

\section{Graph 1: Expressing Emotions, Passivation and Planning and Taking Action by Gender}

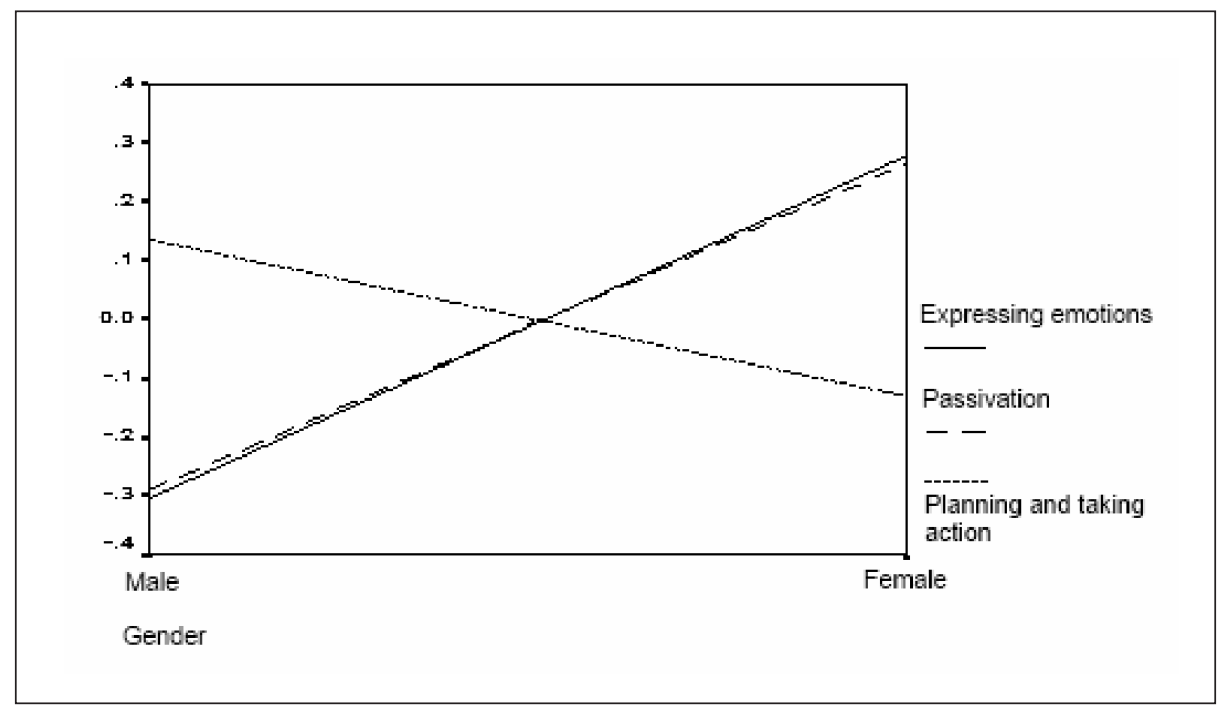

According to most researchers, gender differences in coping with stress are the result of traditional stereotypes about gender roles implying that men are more active and act constructively and instrumentally, while women are more passive and use emotions to express themselves (Stone \& Neale, 1984, Pearlin \& Schooler, 1978). Additionally, unemployed women show more symptoms of depression and have poorer mental health than unemployed men (McKee-Rayan et al., 2005), which might also be the reason for a greater tendency toward the use of emotion-focused coping strategies in women and toward the use of problem-focused coping strategies in men. In fact, Smari et al. (1997) discovered that increased anxiety and depression are related to the use of emotion-focused coping strategies, while decreased anxiety and depression are associated with the use of problem-focused coping strategies.

Age significantly affects three emotion-focused strategies for coping with unemployment stress - expressing emotions $(\mathrm{F}(4)=2.939$; Sig. $=.021)$, reconciliation with destiny $(F(4)=3.826$; Sig. $=.005)$ and passivation $(F(4)=3.476$; Sig. $=.009)($ Table 4). 
Biljana Mirković, Svetlana Čizmić, Active Job Search: The Influence of Socio-demographic Characteristics

Table 4: Descriptive Statistics and F Test for Age, Expressing Emotions, Reconciliation with Destiny and Passivation

\begin{tabular}{llrrrrr}
\hline \hline $\begin{array}{l}\text { Stress coping } \\
\text { strategies }\end{array}$ & Age & AM & SD & N & F(4) & Sig. \\
\hline Expressing & 25 and younger & .064 & 1.085 & 19 & & \\
emotions & $26-35$ & -.087 & 1.011 & 150 & & \\
& $36-45$ & .162 & .940 & 63 & 2.939 & .021 \\
& $46-55$ & -.099 & .978 & 64 & & \\
& $56-65$ & .996 & .650 & 8 & & \\
\hline Reconciliation with & 25 and younger & .113 & 1.102 & 19 & & \\
destiny & $26-35$ & -.146 & 1.028 & 150 & & \\
& $36-45$ & .081 & .932 & 63 & 3.826 & .005 \\
& $46-55$ & .087 & .913 & 64 & & \\
& $56-65$ & 1.138 & .561 & 8 & & \\
\hline Passivation & 25 and younger & -.098 & 1.195 & 19 & & \\
& $26-35$ & -.159 & 1.020 & 150 & & \\
& $36-45$ & .099 & .845 & 63 & 3.476 & .009 \\
& $46-55$ & .193 & .978 & 64 & & \\
\hline \hline
\end{tabular}

The oldest participants (aged over 56) were most inclined to use emotion-focused coping strategies - expressing emotions, reconciliation with destiny and passivation, while young adults (26-35) were least inclined to use the above mentioned strategies for coping with unemployment stress (Graph 2).

\section{Graph 2: Expressing Emotions, Reconciliation with Destiny and Passivation by Age}

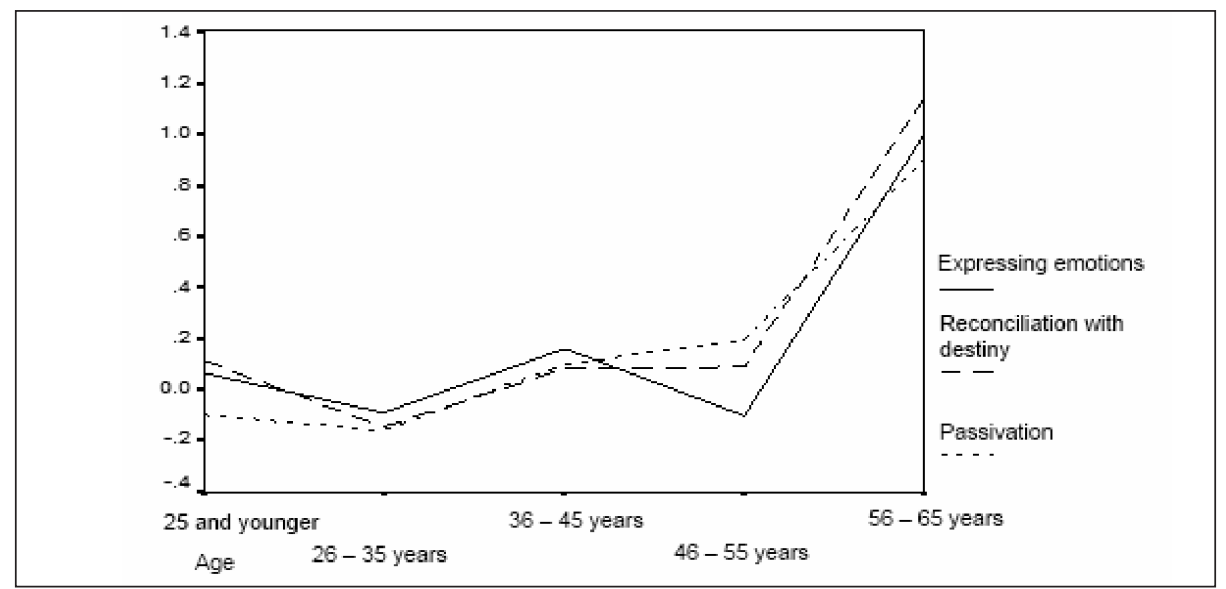


The fact is that labour market favours younger persons (Employment Service of the Republic of Srpska, 2009). Older unemployed people are most probably aware of their decreased chances for employment, either because of their obsolete skills and knowledge, or because of the general unwillingness of employers to hire older people. Assessing that they have no personal control over the situation, i.e. that they cannot alter it by taking action, older people choose passive ways of coping aimed at the regulation of emotions (Lazarus \& Folkman, 2004).

Level of education significantly affects two problem-focused stress coping strategies - planning and taking action $(\mathrm{F}(4)=4.653$; Sig. $=.001)$ and reinterpretation $(\mathrm{F}(4)$ $=3.393 ;$ Sig. $=.010)($ Table 5).

Table 5: Descriptive Statistics and F Test for Level of Education, Planning and Taking Action, and Reinterpretation

\begin{tabular}{|c|c|c|c|c|c|c|}
\hline Stress coping strategies & Level of education & $\mathrm{AM}$ & SD & $\mathrm{N}$ & $\mathrm{F}(4)$ & Sig. \\
\hline \multirow[t]{5}{*}{$\begin{array}{l}\text { Planning and taking } \\
\text { action }\end{array}$} & $\begin{array}{l}\text { Elementary school degree or } \\
\text { less }\end{array}$ & -.063 & .705 & 26 & \multirow{5}{*}{4.653} & \multirow{5}{*}{.001} \\
\hline & $\begin{array}{l}\text { Skilled or highly-skilled } \\
\text { workers }\end{array}$ & -.377 & 1.066 & 53 & & \\
\hline & High school degree & -.044 & 1.112 & 138 & & \\
\hline & College degree & .192 & .679 & 33 & & \\
\hline & University degree or higher & .398 & .744 & 54 & & \\
\hline \multirow[t]{5}{*}{ Reinterpretation } & $\begin{array}{l}\text { Elementary school degree or } \\
\text { less }\end{array}$ & .176 & .882 & 26 & \multirow{5}{*}{3.393} & \multirow{5}{*}{.010} \\
\hline & $\begin{array}{l}\text { Skilled or highly-skilled } \\
\text { workers }\end{array}$ & .299 & .815 & 53 & & \\
\hline & High school degree & -.217 & 1.063 & 138 & & \\
\hline & College degree & .130 & .843 & 33 & & \\
\hline & University degree or higher & .097 & 1.047 & 54 & & \\
\hline
\end{tabular}

People with higher education degrees (college and university degrees or higher) were found to be most apt to choose the strategy of planning and taking action, while artisans (skilled or highly-skilled workers) are least inclined towards this strategy for coping with unemployment stress. Artisans, as well as people with higher education degrees, are most inclined towards reinterpretation, while people with high school degrees are least inclined towards reinterpretation (Graph 3). 
Graph 3: Planning and Taking Action, and Reinterpretation by Level of Education

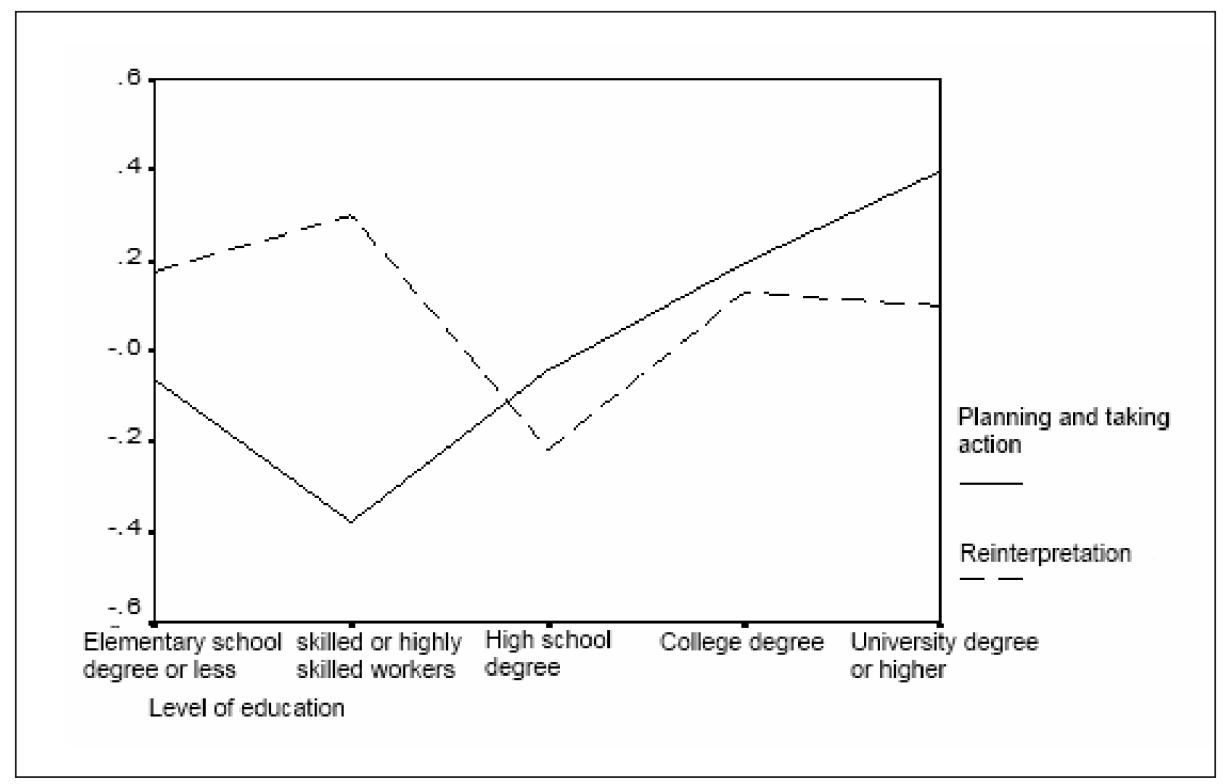

People with a higher level of education probably cope with unemployment stress proactively since they realize they have better chances of finding a job. In fact, employees at the Employment Service of the Republic of Srpska confirm that more educated persons find employment "more easily". People with a higher level of education are more confident in their own ability to successfully compete with others for a position (Govan et al., 1999). The study by Šverko et al. showed that more educated unemployed people more often saw the cause of and solutions for their unemployment in their own traits and behaviour, unlike the less educated unemployed people who found the same more frequently in some of the current socio-economic circumstances, which might account for a greater tendency toward proactive coping with unemployment stress in people with a higher level of education. Our study showed that artisans (skilled or highly skilled workers) were also inclined to problem-focused coping strategy - reinterpretation. When it comes to chances for employment, artisans might consider themselves equal to the people holding college and university degrees resulting from the traditional stereotype that the "craft is worth gold".

The length of unemployment has a considerable effect only on one of the emotion-focused stress coping strategies - reconciliation with destiny $(F(2)=3.386$; Sig. $=.035)$ (Table 6). 
Table 6: Descriptive Statistics and F Test for Length of Unemployment and Reconciliation with Destiny

\begin{tabular}{|c|c|c|c|c|c|c|}
\hline Stress coping strategies & $\begin{array}{l}\text { Length of } \\
\text { unemployment }\end{array}$ & $\mathrm{AM}$ & SD & $\mathrm{N}$ & $F(2)$ & Sig. \\
\hline \multirow[t]{3}{*}{ Reconciliation with destiny } & Up to 6 months & -.544 & .952 & 18 & & \\
\hline & 7-36 months & -.048 & 1.008 & 97 & 3.386 & .035 \\
\hline & More than 36 months & .076 & .987 & 189 & & \\
\hline
\end{tabular}

People who were unemployed for less than six months were found to be less apt to reconciliation with destiny, while those unemployed for over 36 months were most inclined to apply this kind of strategy for coping with unemployment stress (Graph 4).

\section{Graph 4: Relation between Length of Unemployment and Reconciliation with Destiny}

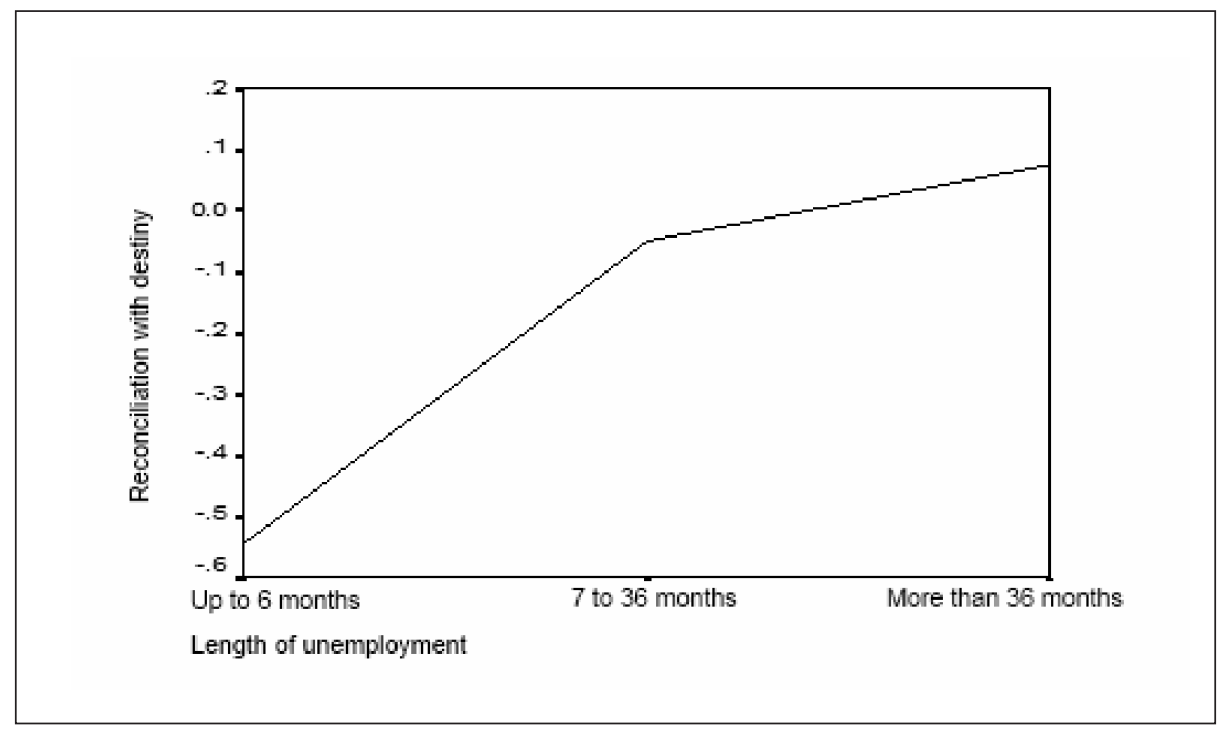

People who have been employed for a long time have probably already experienced failure in their attempts to find a job, these failures usually leading to discouragement and reconciliation with destiny.

Material circumstances affect two emotion-focused stress coping strategies passivation $(F(3)=3.778$; Sig. $=.011)$ and expressing emotions $(F(3)=2.461$; Sig. $=$ $.063)$, the impact being marginally significant; and also one problem-focused strategy -planning and taking action $(F(3)=13.487$; Sig. $=.000)($ Table 7). 
Biljana Mirković, Svetlana Čizmić, Active Job Search: The Influence of Socio-demographic Characteristics

Table 7: Descriptive Statistics and F Test for Material Circumstances, Expressing Emotions, Passivation, and Planning and Taking Action

\begin{tabular}{llrrrrr}
\hline \hline Stress coping strategies & Material circumstances & AM & SD & N & F(3) & Sig. \\
\hline Expressing emotions & Far below the average & .211 & .930 & 101 & & \\
& Just below the average & -.035 & 1.020 & 65 & 2.461 & .063 \\
& Average & -.134 & .986 & 126 & & \\
& Above the average & -.182 & 1.380 & 12 & & \\
\hline Passivation & Far below the average & .258 & .844 & 101 & & \\
& Just below the average & -.038 & 1.020 & 65 & 3.778 & .011 \\
& Average & -.161 & 1.022 & 126 & & \\
& Above the average & -.271 & 1.454 & 12 & & \\
\hline Planning and Taking & Far below the average & .244 & .679 & 101 & & \\
Action & Just below the average & .250 & .841 & 65 & 13.487 & .000 \\
& Average & -.199 & 1.093 & 126 & & \\
& Above the average & -1.319 & 1.540 & 12 & & \\
\hline \hline
\end{tabular}

People living in material circumstances that were far below the average showed the greatest tendency towards emotion-focused coping strategies expressing emotions and passivation, while people whose material circumstances were above the average were found to be least inclined to use these coping strategies. People living in material circumstances above the average are most inclined to apply problem-focused coping strategy - planning and taking action, while people whose material circumstances are below the average are least inclined to use this strategy for coping with unemployment stress (graph 5).

Having in mind that financial stress correlates positively with anxiety, depression and emotional problems (Klinicki et al., 2000), that increased anxiety and depression are related to the use of emotion-focused coping strategies, and that decreased anxiety and depression are linked to the use of problem-focused coping strategies (Smari et al., 1997), it is no wonder that people appraising their material circumstances as far below the average are more apt to use emotion-focused coping strategies, while those estimating their material circumstances as average and above the average are more inclined to apply problem-focused strategy for coping with unemployment stress. 
Graph 5: Relation between Material Circumstances, Expressing Emotions, Passivation and Planning and Taking Action

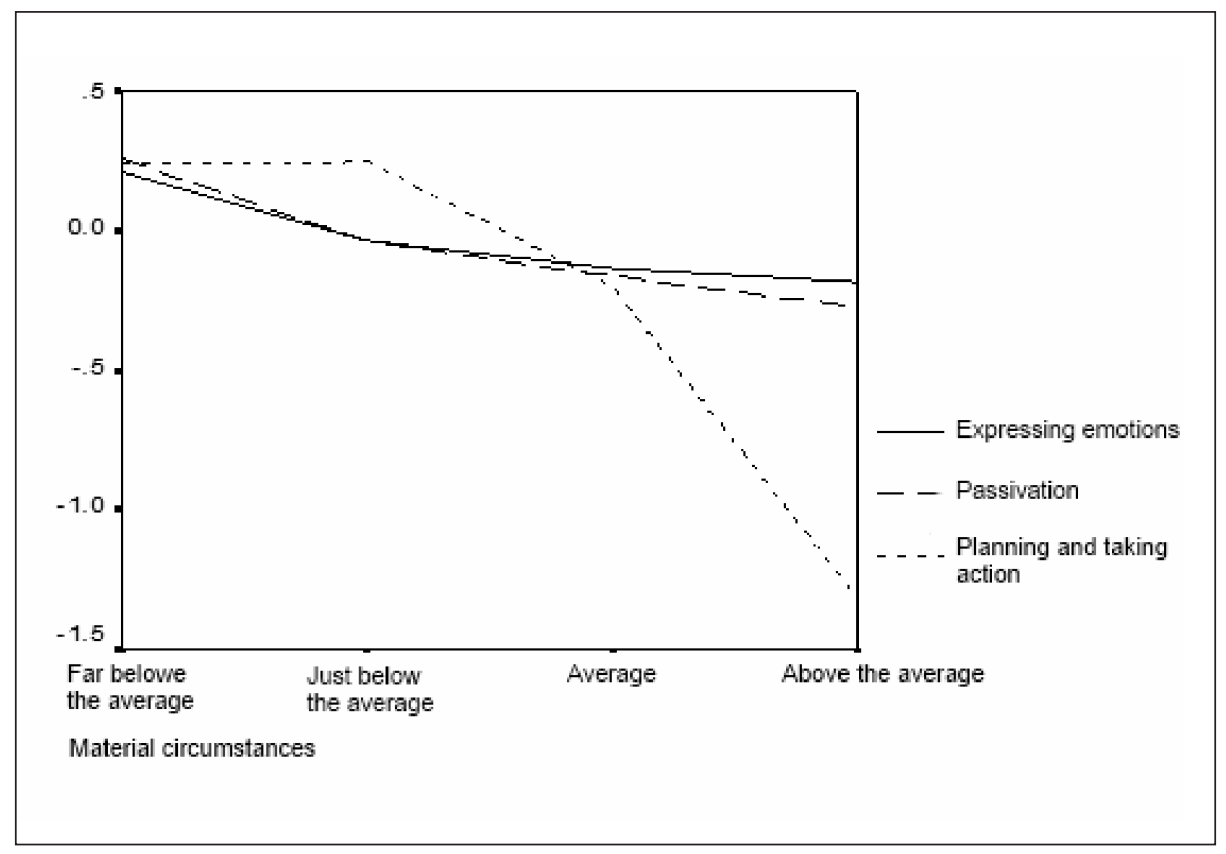

\subsection{Influence of Socio-Demographic Characteristics on Willingness for Active Job Search}

Multivariate analysis of variance and post-hoc test - LSD test - were used to determine the influence of socio-demographic characteristics on willingness for active job search. Mann-Whitney test was used to determine differences between the dichotomic (gender-related) groups.

Upon observing common variance of willingness for active job search, three examined socio-demographic characteristics were found to have a significant impact - gender and education, as well as material circumstances, the effect of which was marginally significant $($ Sig. $=.088)($ Table 8$)$. Common variance of willingness for active job search is not affected by age and the length of unemployment. 
Biljana Mirković, Svetlana Čizmić, Active Job Search: The Influence of Socio-demographic Characteristics

Table 8: Socio-Demographic Characteristics and Common Variance of Willingness for Active Job Search

\begin{tabular}{lcccc}
\hline \hline Socio-demographic characteristics & $\mathrm{F}$ & $\mathrm{df}$ & Error df & Sig. \\
\hline Gender & 2.983 & 4 & 299 & .019 \\
Level of education & 2.594 & 16 & 1196 & .001 \\
Material circumstances & 1.595 & 12 & 897 & .088 \\
\hline \hline
\end{tabular}

Taken individually, willingness for active job search is affected by gender, age, education and material circumstances. There is no significant impact of the length of unemployment.

Gender significantly affects the willingness for usual job search activities ( $\mathrm{U}=$ 9601.000; Sig. $=.032$ ). Its influence is also marginally significant regarding acceptance of position in another city $(\mathrm{U}=10076.000$; Sig. $=.056)($ Table 9).

Table 9: Mean Ranks and Mann-Whitney Test for Gender, Accepting Position in Another City and Usual Activities

\begin{tabular}{llcccc}
\hline \hline Willingness for active job search & Gender & $\mathrm{N}$ & Mean Rank & Mann-Whitney U: & Sig. \\
\hline Accepting position in another city & Male & 145 & 162.51 & \multirow{2}{*}{10076.000} & .056 \\
& Female & 159 & 143.37 & & \\
\hline Willingness for usual activities & Male & 145 & 141.60 & \multirow{2}{*}{0946.500} & .032 \\
& Female & 159 & 162.44 & & \\
\hline \hline
\end{tabular}

Men were found to be more willing to accept the job in another city, whereas women were more willing to pursue usual job search activities (Graph 6).

Since women have a more favourable opinion of Employment Services than men (Daniel, 1990), it is not surprising that they are more willing to pursue usual activities related to job search - reading job vacancy ads in newspapers, applying for vacant positions, maintaining regular contact with the Employment Service employee. On the other hand, men are more prepared to accept a position in another city - implying long daily commuting trips to work and moving to another city for the sake of employment. In view of the fact that the patriarchal pattern according to which a man, as the head of the family, must be its breadwinner, i.e. the main earner, can still be recognized in our society, the obtained findings come as no surprise. The man is expected to do anything to secure income, even to accept a position in another city.

Age considerably affects readiness for corruptive behaviour $(\mathrm{F}(4)=2.493$; $\mathrm{Sig}=$ .043) (Table 10). 


\section{Graph 6: Willingness to Accept Position in Another City and Willingness for Usual Activities by Gender}

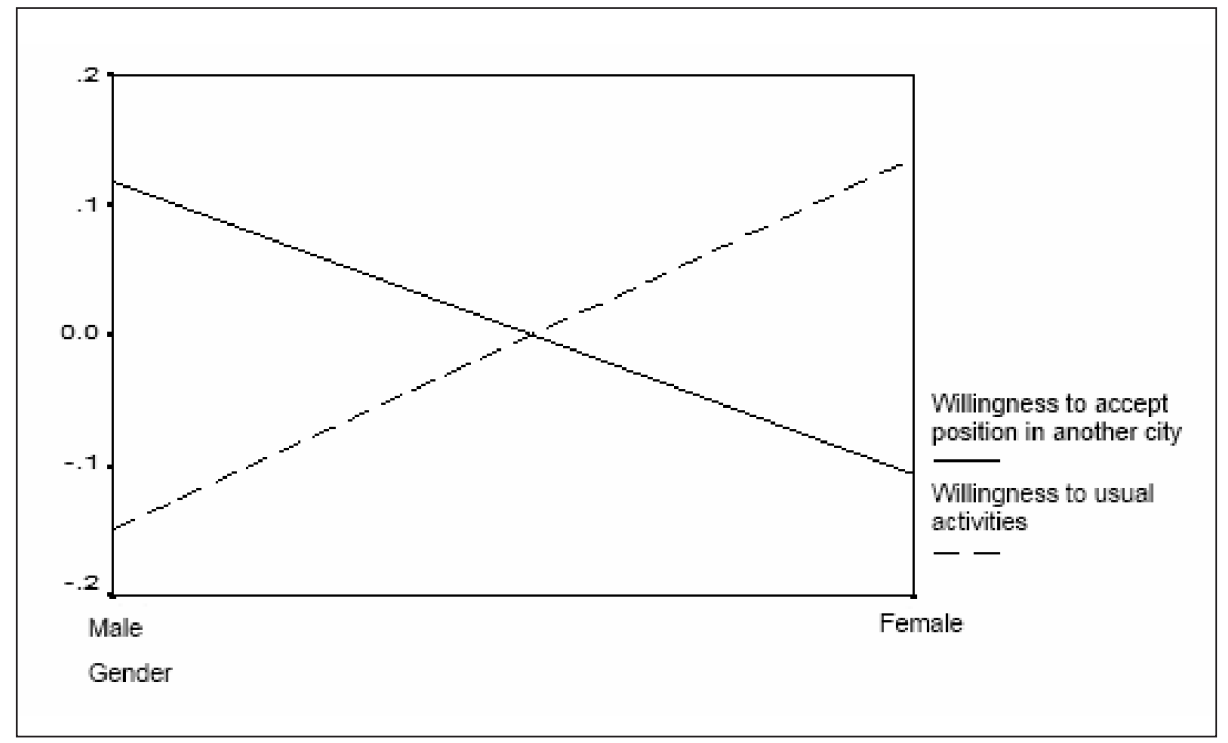

Table 10: Descriptive Statistics and F Test for Age and Readiness for Corruptive Behaviour

\begin{tabular}{llrrrrr}
\hline \hline Willingness for & Age & AM & SD & N & F(4) & Sig. \\
active job search & 25 years and younger & -.234 & 1.095 & 19 & & \\
\hline Readiness for & .120 & .976 & 150 & & \\
corruptive behaviour & $26-35$ years & .090 & 1.000 & 63 & 2.493 & .043 \\
& $36-45$ years & -.229 & .973 & 64 & & \\
& $46-55$ years & -.577 & 1.045 & 8 & \\
\hline \hline
\end{tabular}

Young adults (26-35) were found to be most ready for corruptive behaviour, while late adults (46-55) were least ready for corruptive behaviour while searching for a job (Graph 7). 
Graph 7: Readiness for Corruptive Behaviour by Age

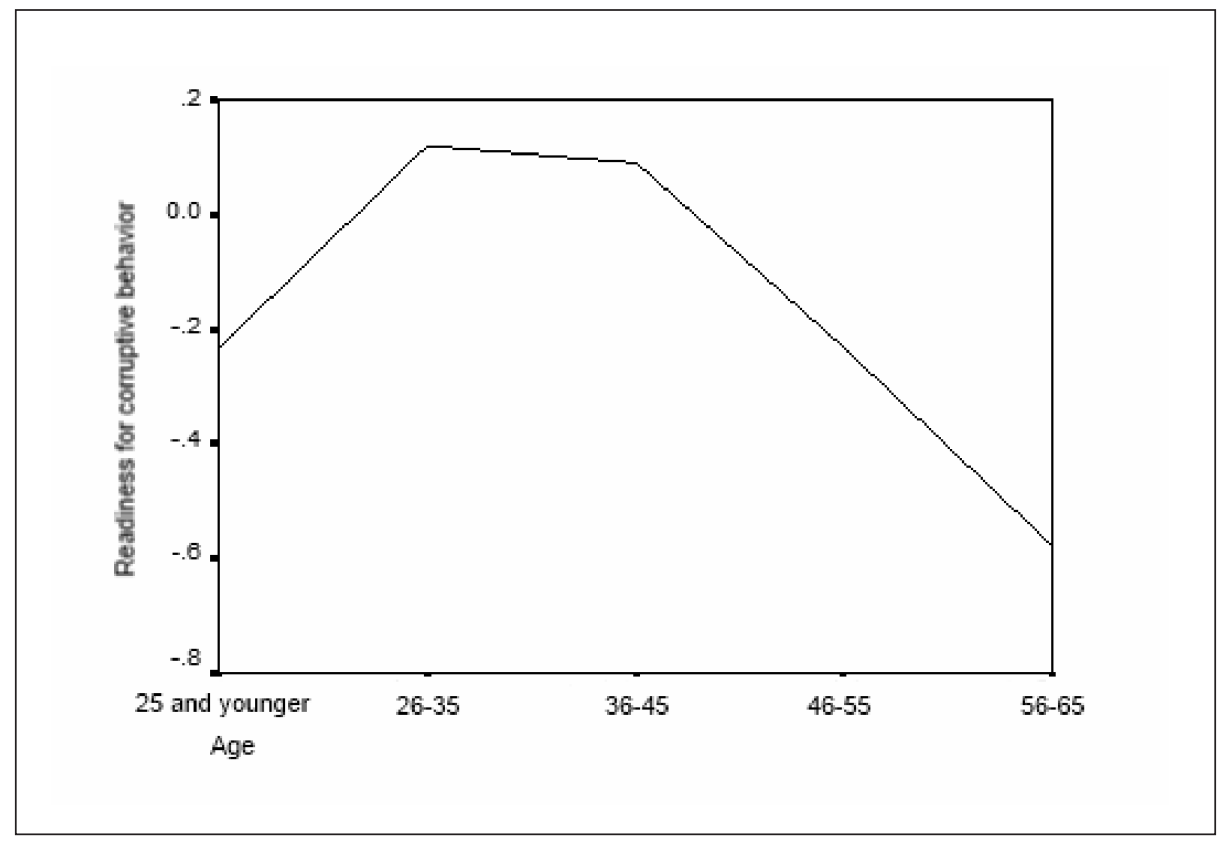

The finding that young adults are most ready for corruptive behaviour while looking for a job can probably be accounted for by greater financial responsibility felt by people of this age and the current situation at the labour market. Namely, in our society people of this age start to live on their own, thus incurring costs of supporting their families and maintaining their households. The economic impact of unemployment is therefore probably higher for them. On the other hand, there are not many job vacancy adverts, private companies are even no longer obliged to place them, and it is an open secret that the fastest and easiest way to find a job is to use some forms of corruptive behaviour, such as: using connections through friends/cousins, giving a bribe, becoming a member of a political party, and so on.

Level of education has a marginally significant effect on the readiness for corruptive behaviour $(\mathrm{F}(4)=2.493$; Sig. $=.081)$ and willingness for usual activities $(\mathrm{F}(4)=$ 2.493; Sig. $=.062)($ Table 11). 
Table 11: Descriptive Statistics and F Test for Level of Education, Corruptive Behaviour and Usual Activities

\begin{tabular}{|c|c|c|c|c|c|c|}
\hline $\begin{array}{l}\text { Willingness for active job } \\
\text { search }\end{array}$ & Level of education & $\mathrm{AM}$ & SD & $\mathrm{N}$ & $\mathrm{F}(4)$ & Sig. \\
\hline \multirow[t]{5}{*}{ Corruptive behaviour } & $\begin{array}{l}\text { Elementary school degree or } \\
\text { less }\end{array}$ & -.097 & 1.101 & 26 & \multirow{5}{*}{2.096} & \multirow{5}{*}{.081} \\
\hline & $\begin{array}{l}\text { Skilled or highly skilled } \\
\text { workers }\end{array}$ & -.300 & .950 & 53 & & \\
\hline & High school degree & .079 & .993 & 138 & & \\
\hline & College degree & -.092 & 1.045 & 33 & & \\
\hline & University degree or higher & .196 & .944 & 54 & & \\
\hline \multirow[t]{5}{*}{ Usual activities } & $\begin{array}{l}\text { Elementary school degree or } \\
\text { less }\end{array}$ & .016 & 1.299 & 26 & \multirow{5}{*}{2.272} & \multirow{5}{*}{.062} \\
\hline & $\begin{array}{l}\text { Skilled or highly skilled } \\
\text { workers }\end{array}$ & .047 & .942 & 53 & & \\
\hline & High school degree & -.169 & 1.034 & 138 & & \\
\hline & College degree & .243 & .700 & 33 & & \\
\hline & University degree or higher & .230 & .902 & 54 & & \\
\hline
\end{tabular}

People with high school and college degrees were found to be most ready for corruptive behaviour, while artisans (skilled and highly skilled workers) were least prone to corruptive behaviour while looking for a job. People with higher education degrees were most willing to pursue usual activities related to job search, while the people with high school education were least ready for them (Graph 8).

\section{Graph 8: Readiness for Corruptive Behaviour and Willingness for} Usual Activities by Level of Education

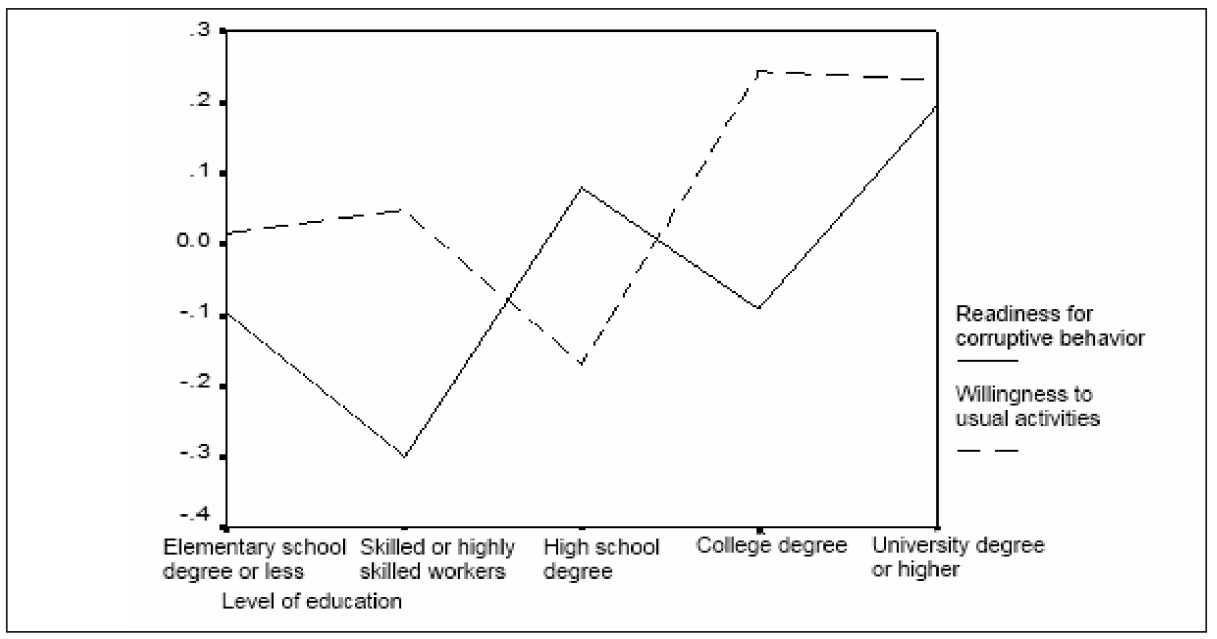


People with a higher level of education may, on one side, believe they have better prospects of getting a job owing to their qualifications, while, on the other side, they are also aware of the fact that corruptive behaviour is the usual way of getting a job in our society. Besides, people with a high school degree probably think that ,connections" and „bribe“ are the only things that can help them to find a job, considering the fact that they make up the largest group in the labour supply at the moment.

Material circumstances have a marginally significant impact on readiness for corruptive behaviour $(\mathrm{F}(3)=2.244$; $\mathrm{Sig}=.083)($ Table 12).

Table 12: Descriptive Statistics and F Test for Material Circumstances and Corruptive Behaviour

\begin{tabular}{llrrrrr}
\hline \hline $\begin{array}{l}\text { Willingness for active job } \\
\text { search }\end{array}$ & Material circumstances & AM & SD & N & F(3) & Sig. \\
\hline Corruptive behaviour & Far below the average & -.091 & .964 & 101 & & \\
& Just below the average & -.147 & 1.135 & 65 & 2.244 & .083 \\
& Average & .171 & .926 & 126 & & \\
& Above the average & -.238 & 1.115 & 12 & \\
\hline \hline
\end{tabular}

People living in average material circumstances were found to be the most willing for corruptive behaviour while searching for a job, while people with material circumstances below the average were the least ready for corruptive behaviour in job search (Graph 9).

\section{Graph 9: Readiness for Corruptive Behaviour by Material Circumstances}

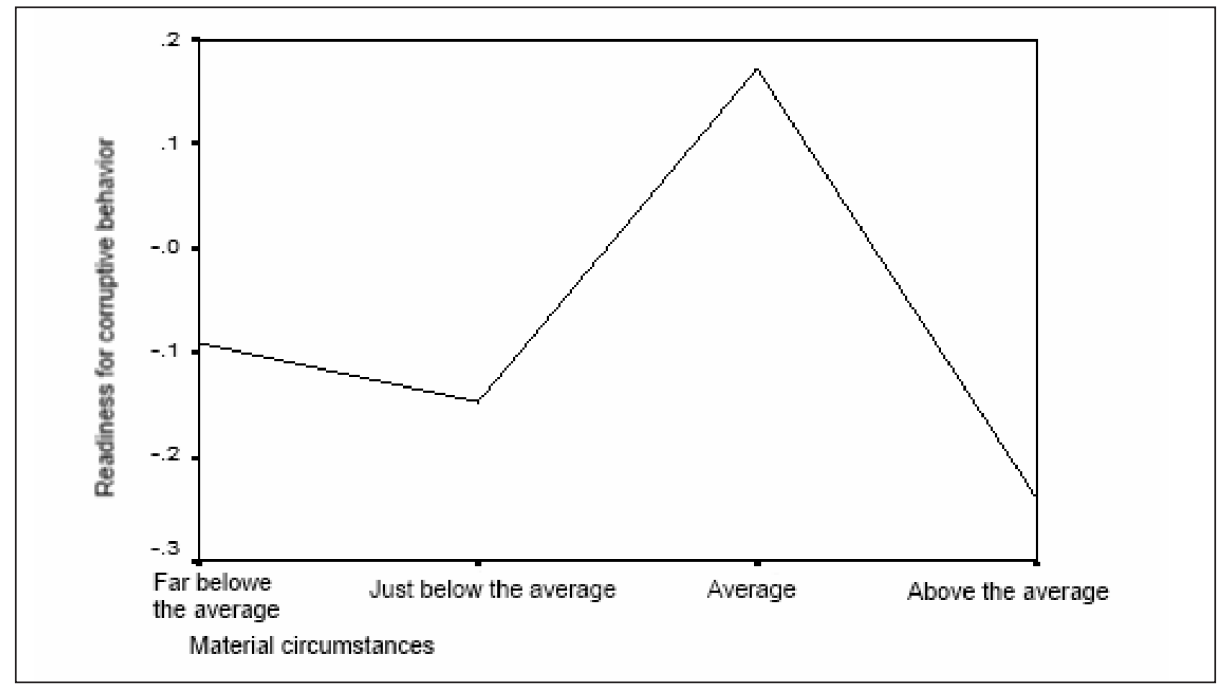


The fact that people living in average material circumstances are the most ready to adopt corruptive behaviour in job search is not surprising, since corruptive behaviour is the fastest and easiest way of getting a job in our society. On the other hand, these people can afford a „bribe“ in return for a job, unlike the people whose material circumstances are below the average.

\subsection{Influence of Strategies for Coping with Unemployment Stress on Willingness for Active Job Search}

Multiple regression analysis was used to determine the success of prediction of willingness for active job search based on strategies for coping with unemployment stress.

Stress coping strategies were found to be significant predictors of one's willingness to use different forms of active job search. What they predict best is the willingness for usual activities in job search $\left(\mathrm{R}_{\llcorner}=14.5 \%\right.$, Sig. <.01) (Table 13).

\section{Table 13: Regression Coefficients for Strategies for Coping with Unemployment Stress and Willingness for Different Forms of Active Job Search}

\begin{tabular}{lcccc}
\hline \hline Willingness for active job search & $\mathrm{R}^{2}$ & Adjusted $\mathrm{R}^{2}$ & $\mathrm{~F}$ & Sig. \\
\hline Corruptive behaviour & .050 & .034 & 3.117 & .009 \\
Accepting a position in another city & .046 & .030 & 2.868 & .015 \\
Accepting a position not related to their & .058 & .042 & 3.650 & .003 \\
profession or qualification & .159 & .145 & 11.262 & .000 \\
Usual activities &
\end{tabular}

In view of the contribution of individual stress coping strategies to prediction of one's willingness for different forms of active job search, problem-focused strategies were found to be significant predictors of willingness for all examined forms of active job search (Table 14). People inclined to planning and taking action turned out to be more willing to carry out usual job search activities $($ Beta $=.300$; $\mathrm{Sig}=.000)$, accept a position in another city $($ Beta $=.243$; Sig. $=.000)$ and accept a position not related to their profession or qualifications $($ Beta $=.200$; Sig. $=.003$ ), while people more inclined to reinterpretation were more willing for usual activities (Beta $=.119$; Sig. $=$ .040 ) and less ready for corruptive behaviour (Beta $=-.168$; Sig. = .007). Among emotion-focused strategies for coping with unemployment stress, only one of them - passivation - is a significant direct predictor of willingness for one single form of active job search - corruptive behaviour $($ Beta $=.178$; Sig. $=.011)$. People inclined to passivation are more ready to adopt corruptive behaviour when looking for a job. 
Biljana Mirković, Svetlana Čizmić, Active Job Search: The Influence of Socio-demographic Characteristics

Table 14: Contribution of Stress Coping Strategies to Prediction of Willingness for Different Forms of Active Job Search

\begin{tabular}{llcc}
\hline \hline Willingness for active job search & Stress coping strategies & Beta & Sig. \\
\hline Corruptive behaviour & Passivation & .178 & .011 \\
Accepting a position in another city & Reinterpretation & -.168 & .007 \\
Accepting a position not related to their & Planning and taking & .243 & .000 \\
profession or qualification & action & .200 & .003 \\
Usual activities & & .300 & .000 \\
\hline \hline
\end{tabular}

Since the function of problem-focused coping is to change the situation leading to stress, and the function of emotion-focused coping is to control emotional reactions caused by a stressful situation, the obtained results were in accordance with the expectations. People oriented towards changing the stress-causing situation were expected to be more willing to use forms of active job search than people who directed their efforts towards finding ways to make coping with negative emotions easier. Similarly, Gowan et al. (1999) determined a positive correlation between emotion-focused coping strategies and re-employment only when the study included exclusively emotionfocused coping strategies. When the study encompassed problem-focused coping strategies as well, only those strategies proved to be good predictors of re-employment. Finally, it is interesting to notice that exactly the people apt to passivation were more ready to adopt corruptive behaviour. The reason behind this might be that only corruptive behaviour leaves them enough time and space to deal with their emotions, since their problem - search for a job - is practically being solved for them by other people - friends, relatives or those given a bribe.

\section{Conclusion}

Perseverance and high involvement are vital for success in finding employment. What makes a difference among the individuals is the amount of effort and involvement they are ready to invest in order to get a job. Additionally, most people find unemployment a stressful experience (Cassidy, 1994, 2001; Broman et al., 2001; Goldsmith \& Veum, 1996). Findings on the factors of differences in willingness to undertake activities aimed at finding a job, are important and useful for creating counselling programmes for the unemployed.

The purpose of this study was to examine the impact of socio-demographic characteristics on the choice of strategies for coping with unemployment stress and willingness for various forms of active job search, as well as to determine whether willingness for active job search can be predicted on the basis of the strategies used for coping with unemployment stress. 
According to the findings, socio-demographic characteristics - gender, age, level of education, length of unemployment and material circumstances - do affect the choice of strategies to be used for coping with unemployment stress. Men, artisans, people with a higher level of education, as well as those living in average material circumstances and those above the average, are more inclined to use problem-focused stress coping strategies. Women, older people, people unemployed for more than three years and those living in material circumstances far below the average are more inclined to use emotion-focused strategies.

Socio-demographic characteristics such as gender, age, level of education and material circumstances do affect the willingness for various forms of active job search. Young adults, people with university and high school education, and people living in average material circumstances are the most ready for corruptive behaviour, while late adults and people whose material circumstances are below the average are the least ready for corruptive behaviour. Women and people with university degrees are most willing to undertake usual job search activities, while men and people with high school degrees are the least ready to do so. Men are more willing to accept a position in another city. Still, socio-demographic characteristics affect the willingness for various forms of active job search to a lesser degree than the choice of strategies for coping with unemployment stress (there are only few socio-demographic characteristics significantly affecting the common variance of willingness for active job search, their impact often being marginally significant).

Strategies for coping with unemployment stress are significant predictors of willingness for various forms of active job search. Specifically, problem-focused coping strategies are significant predictors of willingness for all examined forms of active job search. People more inclined to planning and taking action are more willing to undertake usual job search activities, accept a position in another city and accept a position not related to their profession or qualifications, while those more inclined to reinterpretation are more willing for usual active job search activities and less ready for corruptive behaviour.

Practically, the obtained findings are suggestive of the need for designing different counselling programmes for the unemployed, depending on their socio-demographic characteristics. Some find it useful if they are immediately provided with information about how and where to look for a job, and how to better present themselves in a CV and during interviews. For others, actions aimed at creating problemfocused strategies for coping with unemployment stress could directly contribute to active job search. 


\section{BIBLIOGRAPHY}

Андрић, М. (2004). Корелайи акӣивної ӣражења йосла. Одбрањен дипломски рад, Београд: Филозофски факултет.

Arambašić L. (2003). Stres i suočavanje - teorijski modeli i njihove implikacije za problem nezaposlenosti. Suvremena psihologija 6(1): 103-127.

Broman, C.L., Hamilton, V.L. \& Hoffman, W.S. (2001). Stress and distress among the unemployed - Hard times and vulnerable people. New York: Plenum Publishers.

Cassidy, T. (1994). The psychological health of employed and unemployed recent graduates as a function of their cognitive appraisal and coping. Counselling Psychology Quarterly 7(4): 385397.

Cassidy, T. (2001). Self-categorization, coping and psychological health among unemployed midcareer executives. Counselling Psychology Quarterly 14(4): 303-315.

Daniel, W.W. (1990). The Unemployed Flow. London: Policy Studies Institute.

Davidović, N. (2003). Provjera mogućnosti predikcije bihevioralnih namjera nezaposlenih. Odbranjen diplomski rad, Zagreb: Filozofski fakultet.

Goldsmith, A.H. \& Veum, J.R. (1996). The psychological impact of unemployment and joblessness. Journal of Socio-Economics 25(3): 333-358.

Gowan, M.A. \& Gatewood, R.D. (1997). A Model of Response to the Stress of Involuntary Job Loss. Human Resource Management Review 7(3): 277-298.

Gowan, M.A., Riordan, C.M. \& Gatewood, R.D. (1999). Test of a model of coping with involuntary job loss following a company closing. Journal of Applied Psychology 84: 75-86.

Hanisch, K. A. (1999). Job loss and unemployment research from 1994-1998: A review and recommendations for research and intervention. Journal of Vocational Behavior 55: 188-220.

Huffman, M. L., \& Torres, L. (2001). Job search methods: Consequences for gender-based earnings inequality. Journal of Vocational Behavior 58: 127-141.

Hussmanns, R., Mehran, F. \& Verma, V. (1990). Surveys of economically active population, employment, unemployment and underemployment: An ILO manual on concepts and method. Geneva: ILO.

Kanfer, R., Wanberg, C. R., \& Kantrowitz, T. M. (2001). Job search and employment: Apersonality-motivational analysis and meta-analytic review. Journal of Applied Psychology 86: 837-855.

Kinicki, A.J., Prussia, G.E. \& McKee-Ryan, F.M. (2000). A panel study of coping with involutary job loss. Academy of Management Journal 43(1): 90-101.

Lazarus, R.S. (1966). Psychological stress and the coping process. New York: McGraw-Hill.

Lazarus, R. S. \& Folkman, S. (1984). Stress, appraisal and coping. New York: Springer Publishing Company.

Lazarus, R.S. \& Folkman, S. (2004). Stres, procjena i suočavanje. Zagreb: Naklada Slap.

Leana, C.R. \& Feldman, D.C. (1991). Gender Differences in Responses to Unemployment. Journal of Vocational Behavior 38: 65-77.

Leana, C. R. \& Feldman, D. C. (1992). Coping with Job Loss: How Individuals, Organizations and Communities Respond to Layoffs. New York: Lexington books. 
McKee-Ryan, F. M., Song, Z., Wanberg. C. \& Kinicki, A. J. (2005). Psychological and Physical WellBeing During Unemployment: A Meta-Analytic Study. Journal of Applied Psychology 90(1): 53-76.

Pearlin, L. I. \& Schooler, C. (1978). The structure oi coping. Journal of Health and Social Behavior 19: 2-21.

Пејаковић, А. (2009). Повезаности социодемоірафских варијабли са акииивним йражсенем йосла код незайослених жена у Србији. Одбрањен дипломски рад, Београд: Филозофски факултет.

Pennington, D.C. (1997). Osnove socijalne psihologije. Zagreb: Naklada Slap.

Petrović, I., Čizmić, S., Kovačević, P. (2009). Lokus kontrole na radu i aktivno traženje posla. Andragoške studije 2: 307- 322.

Smari, J., Arason, E., Hafsteinsson, H. \& Ingimarsson, S. (1997). Unemployment, coping and psychological distress. Scandinavian Journal of Psychology 38: 151-156.

Statistika. Zavod za zapošljavanje Republike Srpske. $<$ http://www.zzrs.org/statistika/statistika izbor ukupno.asp $>$ 10. 02. 2009.

Stone, A.A., \& Neale, J.M. (1984). A new measure of daily coping: Development and preliminary results. Journal of Personality and Social Psychology 46: 892-906

Šverko, B. (1991). Značenje rada u životu pojedinca: radne vrijednosti, važnost rada i alijenacija. U: Kolesarić, V., Krizmanić, M. i Petz, B. (ur.), Uvod u psihologiju, Zagreb: Prosvjeta, str. 17-56

Šverko, B., Galešić, M. i Maslić-Seršić, D. (2004). Aktivnosti i financijsko stanje nezaposlenih u Hrvatskoj. Ima li osnova za tezu o socijalnoj isključenosti dugotrajno nezaposlenih osoba? Revija za socijalnu politiku 11(3-4): 283-298.

Vinokur, A., Caplan, R. D. (1987). Attitudes and Social Support: Determinants of Job-Seeking Behavior and Well-being among the Unemployed. Journal of Applied Social Psychology 17: 1007-1024.

Vukelić A. (2003). Anomija pojedinih socijalnih grupa suvremenog hrvatskog društva. Doktorska disertacija, Zagreb, Filozofski fakultet

Wanberg, C. R., Watt, J., Rumsey, D. J. (1996). Individuals Without Jobs: An Empirical Study of JobSeeking Behavior and Reemployment. Journal of Applied Psychology 81: 76-87.

Wanberg, C. R., Kanfer, R. \& Rotundo, M. (1999). Unemployed individuals: Motives, jobsearch competencies, and job search constraints as predictors of job seeking and reemployment. Journal of Applied Psychology 84: 897-910. 
Biljana Mirković, Svetlana Čizmić, Active Job Search: The Influence of Socio-demographic Characteristics

Биљана Мирковић

Сажейак

Универзитет за пословни инжењеринг

и менаџмент, Бања Лука

(Босна и Херцеговина)

Светлана Чизмић

Универзитет у Београду

Филозофски факултет

\section{АКТИВНО ТРАЖЕЬЕ ПОСЛА: УТИЦАЈ СОЦИОДЕМОГРАФСКИХ КАРАКТЕРИСТИКА}

Незайосленосии је сииресно искустиво јер особу сйавља у несиїрну сийуацију и захйјева бројне ирромјене у свакодневном живойу. Акииивно ииражене йосла је важан ирредкитор йроналажењ зайослења. Сазнања о чиниоцима разлика у сирремносиии на акииивно ииражене иосла важна су и корисна у креирању савјеитовања за незайослене

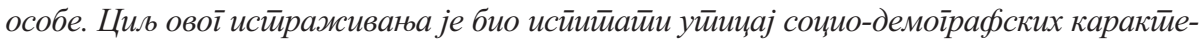
ристиика на избор сіирайейија суочавана са сиресом изазваним незайосленошћу и

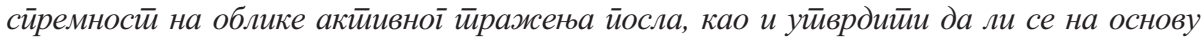
сиирайейја суочавања са сииресом изазваним незайосленошћу може йредвидјейи

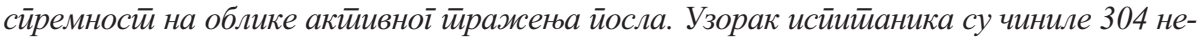
зайослене особе реїисиироване на Заводу за зайошьвване Рейублике Срйске у Баюој Лу-

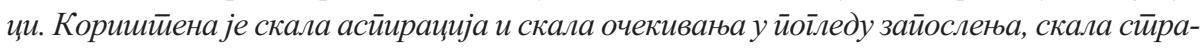
йейја суочавана са сіиресом изазваним незайосленошћу, скала сиремносиии на облике

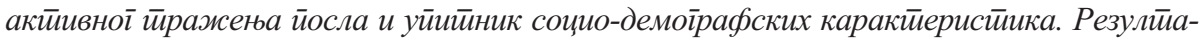
йи су йоказали да на избор сиирайейија суочавана са сииресом изазваним незайослено-

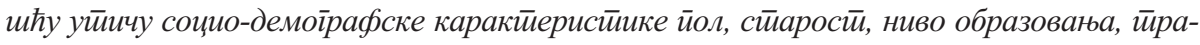

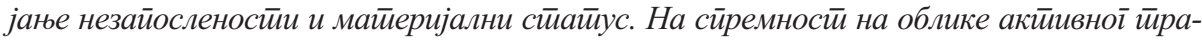

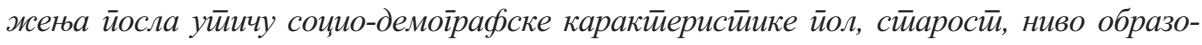
вања и майеријални сииайус. Такође, йоказало се да су йроблему усмјерене сиирайейје суочавана са сииресом изазваним незайосленошћу значајни йредикӣори сйремносиии на облике акииивної йражень йосла.

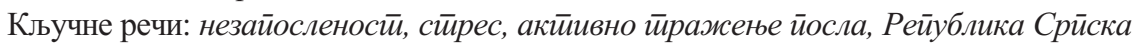

